\title{
Seniorzy w dobie COVID-19
}

\section{Anna Wieczorek}

\section{Wprowadzenie}

Pandemia COVID-19 nie ustępuje. Jest coraz więcej zakażeń, a medycyna wydaje się bezradna. Nie ma leku, nie ma szczepionki. Jedyne co zalecają lekarze, to zrobienie wszystkiego co możliwe, aby uniknąć zakażenia. Proponuje się:

- zachowanie dystansu społecznego,

- noszenie maseczek w przestrzeni publicznej,

- częste mycie rąk,

- dezynfekcję itp.

Wnioski nasuwają się same. Należy zrobić wszystko, aby ograniczyć do minimum kontaktowanie się ludzi. Jednocześnie nie można zatrzymać gospodarki, co oznacza, że zamykanie zakładów pracy nie powinno mieć miejsca. Gdzie w takim razie można i należy ograniczać grupowanie się ludzi? Takimi miejscami są niewątpliwie sklepy, banki, poczty i urzędy.

Najbardziej narażone na zakażenie są osoby w podeszłym wieku. W Polsce jest ponad 9 milionów osób powyżej 60 roku życia. Jeśli wszyscy zachorują na COVID-19, to polska ochrona zdrowia nie ma żadnej szansy ich uratować.

Sytuacja życiowa seniorów jest bardzo zróżnicowana. Jedni są w pełni samodzielni, inni mają kochające rodziny, które się nimi opiekują. Ale są również tacy, którzy w mniejszym lub większym stopniu potrzebują różnego rodzaju pomocy. Wydaje się, że tych ostatnich jest najwięcej.

Żeby podjąć stosowne działania należy odpowiedzieć na pytanie: co trzeba mieć, aby przetrwać pandemię? To niewątpliwie żywność i podstawowe środki czystości, woda w kranie i energia elektryczna oraz ogrzewanie mieszkania. Ponadto, aby nie narobić sobie kłopotów - trzeba zapłacić podatki i inne daniny publiczne. Żeby wiedzieć jaka jest wysokość podatków oraz ile zapłacić za wodę, prąd, gaz itp. trzeba móc odbierać korespondencję.

Wiele osób nie musi chodzić do sklepów i banków, bo załatwia swoje sprawy przez Internet. Żeby móc tak postępować, trzeba mieć odpowiedniej jakości sprzęt (komputer, telefon) oraz odpowiednie umiejętności. Nie wszyscy w Polsce mają dostęp do Internetu, a nawet jeśli mają to nie zawsze umieją poruszać się sprawnie w świecie wirtualnym. Dotyczy to zwłaszcza seniorów.

Możliwość bezpiecznego:

- $\quad$ robienia zakupów, zwłaszcza produktów żywnościowych bez konieczności chodzenia do sklepów,

- odbierania korespondencji, bez konieczności chodzenia na pocztę, 
- opłacania rachunków i podatków bez konieczności chodzenia do banków,

- załatwiania spraw w urzędach bez konieczności chodzenia do ich placówek nie może być uzależniona od posiadania Internetu oraz zaawansowanych umiejętności posługiwania się komputerem i telefonem komórkowym!!!

Korzystanie z usług on-line musi być łatwe, bo tylko w ten sposób zachęci się osoby, które dotychczas z nich nie korzystały, do ich stosowania. Nie może generować nadmiernych kosztów - jeśli ktoś ma stary komputer ze starym oprogramowaniem i stary telefon, za pomocą którego nie jest w stanie odebrać SMS nie przerywając rozmowy telefonicznej, to nie wolno „eliminować go z wirtualnego świata”. Obecnie jest zmuszony do kupowania nowego sprzętu.

Niniejszy artykuł oparto na doświadczeniach autorki i osób jej znanych oraz na powszechnie dostępnych dokumentach. Aby uniknąć posądzenia o kryptoreklamę oraz oskarżeń o pomówienia nie podano nazw sieci handlowych i banków.

\section{Produkty żywnościowe}

Duże sieci handlowe dostarczają produkty żywnościowe, środki czystości, a nawet podstawowe produkty medyczne (plastry, woda utleniona itp.) do domu. Zamówienie składa się przez Internet. Logowanie jest łatwe, nawet dla seniora. Płacić można przez Internet lub przy odbiorze towaru - kartą a nawet gotówką. Dostawcy noszą maseczki i rękawiczki. Jeśli już po przyjęciu towaru okazuje się, że czegoś nie dowieziono, reklamacje są przyjmowane natychmiast, a brakujący towar dostarczany następnego dnia.

Dla osób, które nie są w stanie zrobić zakupów przez Internet, powinny istnieć inne możliwości, np. składanie zamówienia zarówno w dużych sieciach handlowych, jak i w małych sklepach, na osiedlu, gdzie się mieszka:

- przez telefon,

- pisemnie, wrzucając zamówienie do specjalnej skrzynki wystawionej przed sklepem.

Są miejscowości, w których dobrze funkcjonuje handel obwoźny, np. samochód z pieczywem z lokalnej piekarni przyjeżdża do wsi trzy razy w tygodniu.

Być może, aby dostawy do domu opłacały się małym sklepom osiedlowym czy piekarniom, Władze Państwa powinny zastosować zachęty finansowe.

\section{Korespondencja}

W dobie pandemii, coraz częściej listonosze zostawiają awizo w skrzynkach pocztowych, bez względu na to czy ktoś jest w domu czy nie, co skutkuje wydłużeniem kolejek przed placówkami pocztowymi. Zastanowienia wymaga - czy i jaka korespondencja powinna być dostarczana listami poleconymi? Wydaje się, że można ją znacząco ograniczyć. 
Dostawcy prądu i gazu przesyłają faktury listami zwykłymi lub na „zwykły” adres e-mail, bez wymagania posiadania profilu zaufanego. Tak samo postępuje np. Miejskie Przedsiębiorstwo Wodociągów i Kanalizacji w Warszawie. Ale Prezydent Warszawy (jak twierdzą urzędnicy) musi wysyłać decyzje o wysokości podatku od nieruchomości listem poleconym i nie może wysłać ww. decyzji na "zwykły” adres e-mail. Żeby odebrać decyzję w formie elektronicznej trzeba mieć profil zaufany. Skoro podległe Prezydentowi Warszawy Przedsiębiorstwo Wodociągów i Kanalizacji może prowadzić korespondencję listami zwykłymi i na „zwykłe” adresy mailowe, to dlaczego nie można w taki sam sposób wysyłać decyzji o wysokości podatków od nieruchomości? Wodociągi jak widać nie zbankrutowały, co oznacza, że ludzie płacą swoje zobowiązania. Tak samo zapłacą podatki od nieruchomości i inne daniny publiczne. Ci, którzy uchylają się od płacenia, będą to robili bez względu na sposób powiadamiania.

W odpowiedzi na interpelację Pani Poseł Małgorzaty Pępek nr K9INT5035 Pan Wicepremier Jacek Sasin napisał (pismo z dnia 26 maja 2020 r.), że Poczta Polska umożliwia doręczanie przesyłek poleconych w formie elektronicznej. „Doręczanie przesyłek w formie elektronicznej może być realizowane tylko wówczas, gdy adresat wyrazi na to zgodę i upoważni Pocztę Polską S.A. do odbioru przesyłek w celu ich przetworzenia i doręczenia na jego e-Skrzynkę. Do korzystania z usługi wymagane jest posiadanie profilu zaufanego i założenie e-Skrzynki. Aktywacja usługi odbywa się na stronie Poczty Polskiej S.A.: eskrzynka.poczta-polska.pl."

Usługa e-Skrzynki to meteor - zaistniała i już jest likwidowana, a warto żeby została, chociaż zapewne nie wszyscy emeryci mogą z niej korzystać. To usługa dla osób, które mają dostęp do Internetu i sprawnie posługują się komputerem. Poczta Polska mogłaby zaoferować seniorom wykluczonym z możliwości korzystania z tego typu usług następujące rozwiązania:

- listy polecone wrzucać do skrzynek pocztowych, bez konieczności ich kwitowania,

- skanować korespondencję i wysyłać ją na „zwykły” adres mailowy, bez konieczności posiadania profilu zaufanego,

- zmieniać adresy dostarczania przesyłek, bez konieczności przychodzenia do placówek pocztowych.

Odbywałoby się to na prośbę zainteresowanego, wyrażoną w formie pisemnego oświadczenia (z numerem dowodu osobistego, numerem PESEL i numerem telefonu), np.:

- wrzuconego do skrzynki pocztowej,

- wysłanego elektronicznie, „zwykłym” mailem,

- przekazaną listonoszowi.

Ze sprawdzeniem wiarygodności oświadczenia nie powinno być kłopotów. Łatwo ustalić numer dowodu osobistego, do kogo należy adres mailowy oraz czy ktoś przebywa pod wskazanym adresem. 


\section{Opłacanie rachunków}

Wiele osób płaci swoje rachunki przez Internet. Na początku pandemii nie było możliwe uruchomienie takiej usługi bez osobistego stawienia się w placówce banku. Obecnie jest to już możliwe. Niestety banki stosują szereg udziwnień, które zdaniem informatyków nie chronią pieniędzy klientów, ale utrudniają im życie. Przykładowo, jeden z banków, aby odblokować konto klienta, żąda żeby w trakcie rozmowy telefonicznej z pracownikiem banku odebrać SMS nie przerywając rozmowy i odczytać jego treść. Informatykowi, który to wymyślił, zapewne nie przyszło nawet do głowy, że ktoś może mieć „stary” telefon, bez takiej funkcji.

Szereg osób, które nie posługują się Internetem, rachunki opłaca nadal w placówkach banków, czekając w długich kolejkach. Mogą również złożyć tzw. zlecenie stałe, które polega na tym, że bank wpłaca, na podane konto, taką samą kwotę w określonym terminie.

Rachunki za wodę, prąd, gaz czy telefon są różne w różnych okresach i nie mogą być traktowane jako zlecenie stałe. Opłacanie tego typu rachunków powinno odbywać się na prośbę zainteresowanego, wyrażoną w formie pisemnego oświadczenia (z numerem dowodu osobistego, numerem PESEL i numerem telefonu), w którym podane są numery kont i kwoty:

- $\quad$ wrzuconego do specjalnej skrzynki, stojącej np. przy wejściu do banku,

- wysłanego pocztą elektroniczną lub listem zwykłym.

Z weryfikacją prawdziwości oświadczenia banki nie powinny mieć problemów - mają dane osobowe, wzory podpisów oraz numery telefonów swoich klientów. Wiedza, kto opłaca jakie rachunki. Łatwo sprawdzić, czy np. dostawca prądu wystawił rachunek danej osobie. Dostawcy prądu, wody, gazu czy spółdzielnie mieszkaniowe, za zgodą seniora, mogłyby jego rachunki przekazywać bezpośrednio bankom. Właściciele kont również mogą łatwo sprawdzić, czy ich rachunki zostały zapłacone. Banki wysyłają sprawozdania z dokonanych transakcji, w tym listami zwykłymi. Proponowane rozwiązanie poszerzyłoby usługę, nazywaną przez banki poleceniem zapłaty.

\section{Posumowanie}

Dawno temu krążył makabryczny dowcip. W odpowiedzi na słynne „pomożecie - pomożemy”, delegacja emerytów przyszła do towarzysza Edwarda Gierka i zadała pytanie jak mają pomagać? Towarzysz odpowiedział - pomożecie jak umrzecie.

W obecnej sytuacji - spadek PKB o ponad 8\% - stary dowcip brzmi złowieszczo. Śmierć 9 milionów ludzi znakomicie poprawiłaby stan finansów państwa - nie trzeba by było wypłacać emerytur. Ale żarty na bok - dowcip pochodzi ze słusznie minionej epoki. Obecnie Władze Polski na pewno zrobią wszystko, aby osoby w podeszłym wieku przetrwały pandemię, bezpiecznie robiąc zakupy odbierając przesyłki pocztowe i płacąc rachunki. Wszystko to nie będzie uzależnione od tego czy senior ma dostęp do Internetu, ma nowoczesny 
komputer i telefon oraz umie się tym sprzętem posługiwać. Na pochwałę zasługuje telefon: 22 - 50511 11. Pod tym numerem osoby, które ukończyły 70 lat mogą poprosić o pomoc, np. w robieniu zakupów.

Wprowadzanie nowych usług powinno być adresowane przede wszystkim do najsłabszych, w tym seniorów, tak, aby ograniczyć konieczność ich przebywania w przestrzeni publicznej. Dobrze, że powstaje coraz więcej usługi on-line, ale seniorzy nie zawsze mogą i umieją z tych usług korzystać. Warto zwrócić uwagę parlamentarzystom, szefom banków i poczty, że przy emeryturze 1200 zł brutto seniora nie stać na komputer, nowoczesny telefon i Internet oraz korepetycje u informatyka.

Anna Wieczorek - na Politechnice Warszawskiej ukończyła Wydział Architektury, Podyplomowe Studium Urbanistyki, Studium Doskonalenia Pedagogicznego oraz uzyskała dyplom doktora nauk technicznych. Posiada uprawnienia do projektowania w planowaniu przestrzennym oraz uprawnienia do pełnienia samodzielnych funkcji technicznych w budownictwie. Specjalizuje się w wykonywaniu projektów miejscowych planów zagospodarowania przestrzennego (główny projektant ponad 30 uchwalonych projektów planów miejscowych) oraz projektów studiów uwarunkowań i kierunków zagospodarowania przestrzennego gmin (główny projektant 5 uchwalonych stdiów). Ma doświadczenie w pracy ze studentami - na Politechnice Warszawskiej i w Wyższej Szkole Przedsiębiorczości i Administracji w Lublinie. Należy do Mazowieckiej Okręgowej Izby Architektów z siedzibq w Warszawie oraz Pan-Europejskiej Federacji Ochrony Zabytków - Europa Nostra z siedzibq w Holandii.

Anna Wieczorek - graduate of the Warsaw University of Technology - Faculty of Architecture, Postgraduate Town Planning Studies, Pedagogical study, PhD in technical science. Holds professional permits for spatial planning and is authorised to perform independent technical functions in construction. Specialises in the preparation of local spatial development plans (is the main designer of more than 30 approved local development plans) and of the studies of conditions and directions of the spatial development of municipalities (main designer of 5 approved studies). Has experience in working with students - at the Warsaw University of Technology and the University College of Enterprise and Administration in Lublin. Member of the Warsaw-based Masovian Chamber of Architects and the Pan-European Federation for Cultural Heritage, Europa Nostra based in the Netherlands. 